\title{
Bridge Jobs and Partial Retirement
}

By: Christopher J. Ruhm

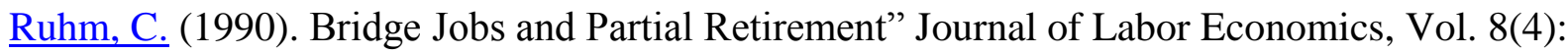
482-501.

Made available courtesy of The University of Chicago Press. Copyright @1990

$* * *$ Note: Figures may be missing from this format of the document

$* * *$ Note: Footnotes and endnotes indicated with parentheses

\begin{abstract}
:
The "job-stopping" process of older workers often includes some combination of postcareer "bridge" employment, partial retirement, and reverse retirement. Fewer than two-fifths of household heads retire directly from career jobs, over half partially retire at some point in their working lives, and a quarter reenter the labor force after initially retiring. In addition, postcareer employment is frequently located outside the industry and occupation of the career job, and there are important differences in postcareer labor force experiences by gender, permanent income, and career-job pension status.
\end{abstract}

\section{Article:}

\section{INTRODUCTION}

The combination of increased longevity and earlier departures from "career" jobs provides most individuals with the opportunity to work for considerable periods of time following the end of traditional employment relationships. This article examines the employment patterns of adults in the final stages of their working lives, with special attention paid to the transition period that follows the end of career positions and precedes permanent retirement. The "job-stopping" process - which frequently includes intervals of postcareer "bridge" employment, partial retirement, and reverse retirement-is poorly understood by economists and policy- makers and has been the subject of relatively little research.

After finishing school, most individuals pass through what has variously been called a "moratorium" or "job-shopping" period, which is characterized by a lack of commitment to particular jobs, dead-end employment, and intermittent labor force participation. ${ }^{1}$ Subsequently, the majority of young adults obtain stable career positions that last for a substantial portion of their working lives. Although the youth and career employment phases are fairly well understood, much less is known about the final stages of work that, for many individuals, consist of one or more transitional jobs that bridge the period between the end of career employment and ultimate withdrawal from the labor force.

Postcareer labor force participation differs from career employment in several important respects. Bridge jobs are generally located in different industries or occupations from career positions. They also frequently imply reduced or intermittent attachment to the labor force. For example, approximately half of all head of households define themselves as partially retired at others.

1. These issues are focused on by Feldstein (1973), Osterman (1980), and Hall (1982), among 
some point in their working lives, and a fourth reenter the labor force after initially retiring. Similarly, over a quarter return to full labor force participation after partially retiring.

Although individuals often remain in the labor force after the end of career positions, older workers continue to have low rates of job mobility. Two-thirds of nonretired household heads hold no more than one job during the 10-year period studied here, and fewer than one in 12 changes employment two or more times. This suggests that the desire for stable employment persists following the termination of career positions and indicates that at least some bridge jobs last for considerable durations. It also raises concern about departures from career jobs induced by the economic incentives in private pension plans or due to involuntary layoffs.

\section{DATA AND SAMPLE}

This article utilizes data on head of households from all six waves of the Social Security Administration Retirement History Longitudinal Survey (RHLS). The RHLS contains information on a random sample of men and unmarried women aged 58-63 in 1969 (the initial survey year), with respondents reinterviewed at 2-year intervals through 1979. Fairly detailed data are available on labor force histories during the survey period (1969-79), as is less specific information on work in the presurvey years. Importantly, questions are included on the longestlasting job held on or prior to 1969.

After excluding persons with no work experience between 1949 and 1969, nonhousehold heads, and those failing to respond in all six waves of the survey, the sample contains 6,633 respondents-5,179 males and 1,454 females. ${ }^{2}$ Throughout the main body of the text, labor force status is determined according to whether respondents classify themselves as "not retired," "partially retired," or "retired." Alternative, more "objective" definitions of retirement status were also considered and are discussed in the Appendix. The "objective" categorizations supplement self-classified status with earnings requirements for complete and partial retirement. Although there are disparities between the self-reported and "objective" retirement classifications, most of the major findings of this article are robust to the choice of definitions.

The majority of respondents move from full labor force participation to retirement during the years covered by the RHLS. For example, less than a quarter consider themselves to be retired or partially retired in 1969 , but over $90 \%$ do so 10 years later (see table 1 ). ${ }^{3}$ Retirement probabilities increase with age. Controlling for age, males, whites, and educated workers are less likely to be retired than their counterparts. Partial retirement also appears to be fairly common for workers in their middle to late sixties.

For purposes of this analysis, the individual's career job is defined as the longest spell of employment with a single firm, up to and including the position held at the beginning of the RHLS. A potential weakness of this definition is that some persons may leave their longest jobs at fairly young ages to undertake second careers, while others never develop strong attachments

2. Nonhousehold heads are excluded because information on them is quite limited. Approximately $30 \%$ of sample attrition is due to death of the respondent, the remainder because they refused to answer or could not be located.

3. For presentation purposes, persons not reporting years of schooling were merged with the less-than-8-year group since results for the two categories are very similar. 
Table 1

Labor Force Status in 1969, 1975, and 1979 (by \%)

\begin{tabular}{|c|c|c|c|c|c|c|c|c|c|c|}
\hline & \multicolumn{3}{|c|}{1969} & \multicolumn{3}{|c|}{1975} & \multicolumn{3}{|c|}{1979} & \multirow[b]{2}{*}{$N$} \\
\hline & Not Retired & Partially Retired & Retired & Not Retired & Partially Retired & Retired & Not Retired & Partially Retired & Retired & \\
\hline $\begin{array}{l}\text { All workers } \\
\text { Age in 1969: }\end{array}$ & 78.0 & 8.4 & 13.6 & 19.9 & 18.9 & 61.3 & 9.0 & 16.6 & 74.4 & 6,633 \\
\hline $58-59$ & 87.1 & 5.1 & 7.8 & 31.7 & 16.8 & 51.5 & 11.1 & 18.7 & 70.2 & 2,391 \\
\hline $60-61$ & 79.3 & 7.8 & 12.9 & 14.7 & 21.3 & 64.0 & 8.1 & 16.5 & 75.4 & 2,194 \\
\hline $62-63$ & 65.9 & 13.0 & 21.1 & 11.6 & 18.7 & 69.7 & 7.4 & 14.3 & 78.3 & 2,048 \\
\hline \multicolumn{11}{|l|}{ Sex: } \\
\hline Male & 80.6 & 7.8 & 11.6 & 20.6 & 19.5 & 59.9 & 9.3 & 17.6 & 73.1 & 5,179 \\
\hline Female & 68.7 & 10.7 & 20.7 & 17.2 & 16.6 & 66.2 & 7.6 & 13.3 & 79.2 & 1,454 \\
\hline \multicolumn{11}{|l|}{ Race: } \\
\hline White & 78.7 & 8.0 & 13.2 & 19.8 & 18.9 & 61.3 & 8.9 & 16.8 & 74.3 & 5,931 \\
\hline Nonwhite & 71.8 & 11.5 & 16.7 & 20.5 & 18.7 & 60.8 & 9.4 & 15.2 & 75.4 & 702 \\
\hline \multicolumn{11}{|l|}{ Education: } \\
\hline$<9^{*}$ & 73.9 & 9.8 & 16.3 & 17.0 & 19.7 & 63.3 & 8.2 & 16.6 & 75.2 & 3,373 \\
\hline $9-12$ & 81.9 & 7.2 & 10.9 & 20.1 & 18.6 & 61.3 & 8.3 & 16.6 & 75.7 & 2,275 \\
\hline$>12$ & 83.0 & 6.3 & 10.7 & 29.0 & 16.7 & 54.3 & 13.1 & 18.0 & 68.9 & 985 \\
\hline
\end{tabular}

SOURCE.-Social Security Administration, Retirement History Longitudinal Survey $(1969,1975,1979)$. Includes head of households remaining in sample through 1979. Labor force status is self-reported by respondent.

${ }^{*}$ Includes persons not reporting years of education received.

to a single employer. To some degree, this concern is mitigated by evidence of an earlier study (Ruhm 1990) indicating that observed patterns of career terminations, bridge-job holding, and retirement are qualitatively similar when persons leaving longest jobs at relatively young ages (i.e., before 55) are excluded from the analysis.

\section{BRIDGE EMPLOYMENT}

Although some workers retire directly following the end of career employment, recent research (Quinn and Burkhauser 1990; Ruhm 1990) suggests that this is the exception rather than the rule. This section considers some characteristics of the bridge jobs held subsequent to career employment and prior to the first reported retirement. The findings can be summarized as follows. First, the early end to career employment implies that most individuals retire from bridge jobs. Second, the duration of postcareer labor force participation is lengthy for a substantial portion of respondents, especially for those departing career positions prior to age 60 . Third, even when employed outside of career jobs, older workers have low rates of mobility. Fourth, movement from career to bridge employment generally involves a switch in industry, occupation, or both, while partial retirement almost always requires some type of sectoral mobility.

\section{A. Incidence and Duration of Postcareer Labor Force Participation}

Most individuals depart their career jobs well before the "normal" age of retirement and work in bridge positions for a number of years. For example, over a fifth of respondents leave career employment prior to age 50, a third before 55, and half earlier than 60 (table 2, col. 5). As a result, only $36 \%$ of household heads retire immediately on the end of their career positions, and nearly half remain in the labor force for at least 5 additional years (row 6). ${ }^{4}$

4. These numbers underestimate the duration of postcareer labor force participation since inprogress spells are truncated in 1979. 
Early departures from career jobs are associated with the lengthiest post-career labor force participation. Nonetheless, the rarity with which young career-job leavers quickly retire is striking. Over $90 \%$ of respondents exiting career positions prior to age 50 remain in the labor force for at least a decade, and fewer than one in 60 promptly retires (row 1). Similarly, almost $70 \%$ of those departing career jobs between 50 and 55 wait 10 or more years before retiring, and only one out of 15 retires immediately (row 2). Although direct movement into retirement becomes more probable for workers terminating career jobs at later ages, a significant proportion continues to participate in the labor force for some time. For example, four in 10 sample members leaving career employment between the ages of 60 and 64 remain in the labor force, two-fifths of these for 5 years or more (row 4). ${ }^{5}$

Table 2

Years in Labor Force after Career Job Ends (by \% of Sample)

\begin{tabular}{|c|c|c|c|c|c|}
\hline \multirow[b]{2}{*}{ Age Career Job Ends } & \multicolumn{4}{|c|}{ Number of Years* } & \multirow{2}{*}{$\begin{array}{c}\text { All } \\
\text { Workers }\end{array}$} \\
\hline & 0 & $1-4$ & $5-9$ & $\geq 10$ & \\
\hline \multicolumn{6}{|l|}{ Full sample: } \\
\hline$<50$ & 1.3 & 3.0 & 3.4 & 92.4 & 22.6 \\
\hline $50-54$ & 6.7 & 10.7 & 12.8 & 69.9 & 11.6 \\
\hline $55-59$ & 11.6 & 27.7 & 34.9 & 25.8 & 17.3 \\
\hline $60-64$ & 59.7 & 23.5 & 11.3 & 5.5 & 30.5 \\
\hline $65-69$ & 76.4 & 18.0 & 5.7 & & 13.2 \\
\hline All workers & 35.9 & 16.5 & 12.5 & 35.1 & \\
\hline \multicolumn{6}{|l|}{$\begin{array}{l}\text { Covered by pension plan } \\
\text { in career job: }\end{array}$} \\
\hline$<50$ & 1.7 & 3.0 & 3.8 & 91.5 & 10.3 \\
\hline $50-54$ & 8.3 & 13.1 & 9.2 & 69.4 & 9.0 \\
\hline $55-59$ & 17.1 & 31.4 & 32.8 & 18.7 & 15.9 \\
\hline $60-64$ & 70.6 & 19.9 & 7.2 & 2.4 & 45.2 \\
\hline $65-69$ & 83.8 & 12.4 & 3.8 & $\ldots$ & 17.3 \\
\hline All covered workers & 52.3 & 17.6 & 10.3 & 19.8 & \\
\hline
\end{tabular}

* Number of years after the end of career employment until first self-report of retirement (or 1979 if not retired by then).

There is no evidence that adverse pension incentives cause career jobs to end prematurely. If anything, the greater stability of these positions translates into later termination ages and shorter periods of bridge employment. Only $19.3 \%$ of covered workers end career positions prior to age 55 , and $35.2 \%$ before 60 (rows $7-9$ ). Nonetheless, almost half (47.7\%) of pension-eligible workers remain in the labor force after their career jobs end, over $60 \%$ of these for at least 5 years (row 12).

Despite the early end to career positions, the employment of older workers tends to be extremely stable. More than two-thirds of respondents participating in the labor force in 1969 do not switch employers during the 10-year observation period; fewer than one in 12 changes firms more than once (table 3, row 1). ${ }^{6}$

5. Bias due to censoring is most severe for workers leaving jobs after age 65 (row 5) since many of these individuals work in their career jobs through 1979 (and are therefore assumed to retire directly from career employment) or leave the positions shortly before 1979 but remain in the labor force past that date.

6. The table shows the number of follow-up surveys at which respondents report changing employers since the previous interview. This slightly understates total turnover since some individuals change jobs several times during a given 2-year period. Analysis of the subsample of RHLS respondents, for whom complete employment histories are available, indicates that this multiple job changing occurs rarely, and correcting for it has little impact on the overall results. 
These percentages are essentially invariant across demographic subgroups or pension status, and there is only the slightest indication that younger sample members hold less stable employment. Surprisingly, the employment of partially retired workers is as stable as that held by their notretired counterparts (see rows 2 and 3 ).

Movement out of the career job is also associated with only small reductions in employment stability. Fewer than $37 \%$ of respondents leaving career jobs prior to 1969 change employers during the observation period (row 17). Although observed turnover rates will automatically be higher for persons ending career jobs after 1969, eight out of 10 workers in this group either accept a single bridge job, at which they stay until retirement, or never obtain subsequent employment (row 18). The low mobility of mature workers indicates a continued desire for stable employment, even after the end of the career job.

\section{B. Changes in Industry or Occupation}

To the extent that sector-specific skills are important, more favorable earnings outcomes are expected when bridge jobs are obtained in the same industry and occupation as career positions than when these attachments are severed. Empirical evidence bears out this supposition. Earnings losses exceeding $25 \%$ are experienced by $61.1 \%$ of household heads leaving career jobs before

\section{Table 3}

\section{$\%$ of Respondents Who Report One or More Job Changes} at Follow-up Interviews

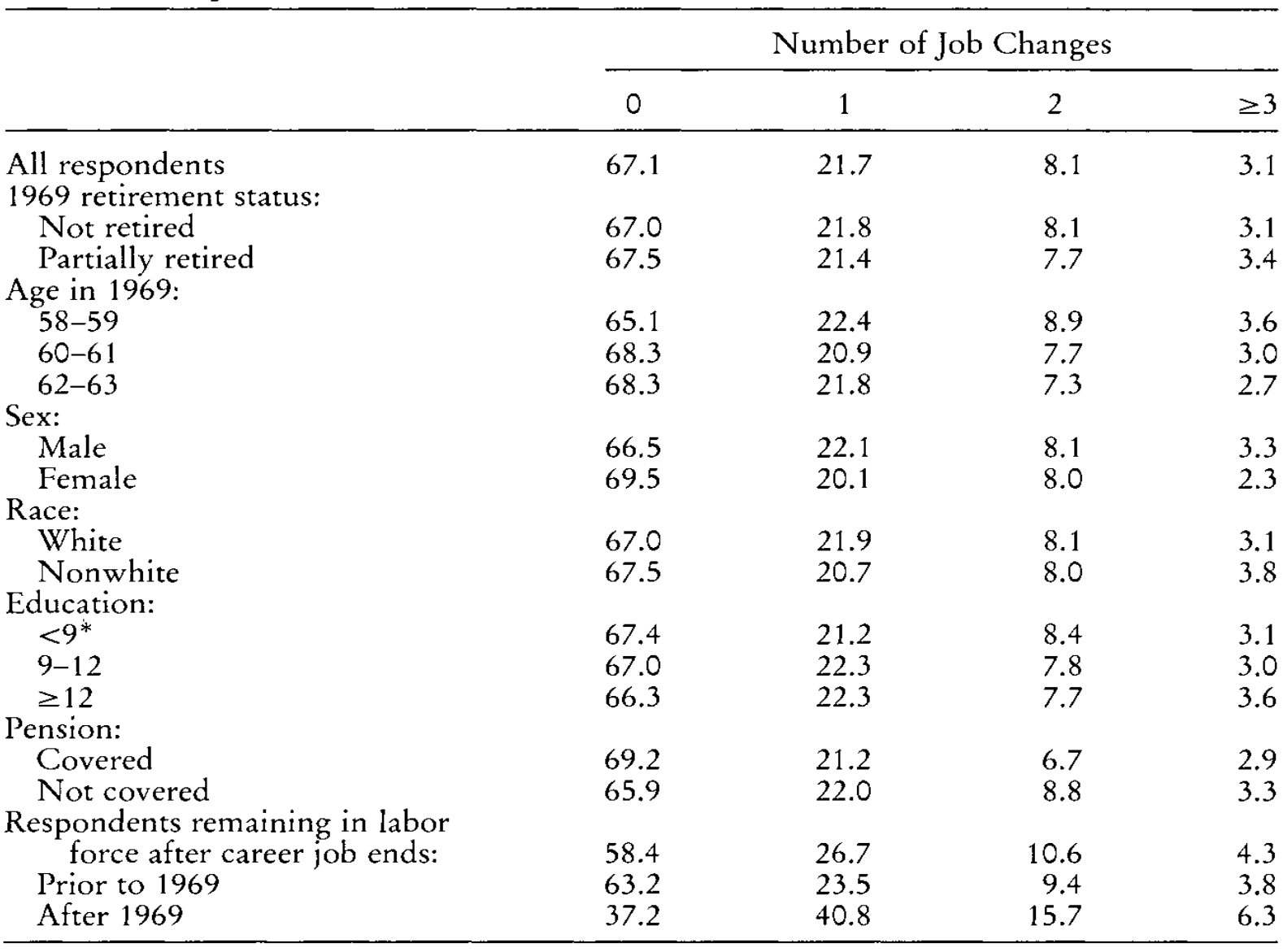

NOTE.-The sample is restricted to persons retiring after $1969(N=5,729)$.

* Includes persons not reporting years of education. 
age 60 who change both one-digit Standard Industrial Classification industry and occupation, by $29.8 \%$ of those changing either industry or occupation (but not both), and by only $15.5 \%$ of respondents remaining in the same industry and occupation. ${ }^{7}$

Despite the high financial costs of changing employment sectors, bridge jobs are rarely located in the same one-digit industry and occupation as career employment. Fewer than a quarter (23.9\%) of respondents remain in their career industry and occupation in their first subsequent position, and barely half $(51.6 \%)$ stay in either the same one-digit industry or occupation (table 4 , row 1). These percentages apply to individuals who are reemployed at the first survey following the end of career employment. To the extent that longer durations of joblessness are associated with higher rates of sectoral change, they understate the prevalence of the latter. Conditional on a job transition taking place, frequent changes of industry or occupation are not automatically inconsistent with substantial investments in firm-specific (rather than sectorspecific) human capital. Career jobs would not be expected to often end prior to retirement, however, if firm- specific skills are of key importance.

The overall averages conceal moderate variation in rates of sectoral change across sample subgroups. Whites, educated workers, individuals without pensions, and those leaving career jobs in their late fifties are relatively more likely to remain in the same industry or occupation.

Table 4

$\%$ of Respondents Remaining in Career Job Sector in First Postcareer Employment

\begin{tabular}{|c|c|c|c|c|}
\hline & Industry & Occupation & $\begin{array}{l}\text { Industry or } \\
\text { Occupation }\end{array}$ & $\begin{array}{l}\text { Industry and } \\
\text { Occupation }\end{array}$ \\
\hline All workers & 36.8 & 38.8 & 51.6 & 23.9 \\
\hline Retirement status: & & & & 276 \\
\hline $\begin{array}{l}\text { Not retired } \\
\text { Partially retired }\end{array}$ & $\begin{array}{l}41.2 \\
22.8\end{array}$ & $\begin{array}{l}43.1 \\
23.7\end{array}$ & $\begin{array}{l}56.7 \\
35.1\end{array}$ & $\begin{array}{l}27.6 \\
11.4\end{array}$ \\
\hline Age career job ends: & & & & \\
\hline $\begin{array}{l}<55 \\
55-59 \\
\geq 60\end{array}$ & $\begin{array}{l}38.8 \\
46.0 \\
21.3\end{array}$ & $\begin{array}{l}39.9 \\
49.9 \\
24.0\end{array}$ & $\begin{array}{l}54.4 \\
61.7 \\
33.8\end{array}$ & $\begin{array}{l}24.2 \\
34.2 \\
11.6\end{array}$ \\
\hline Sex: & & & & \\
\hline $\begin{array}{l}\text { Male } \\
\text { Female }\end{array}$ & $\begin{array}{l}35.9 \\
40.5\end{array}$ & $\begin{array}{l}36.4 \\
49.3\end{array}$ & $\begin{array}{l}49.7 \\
59.8\end{array}$ & $\begin{array}{l}27.2 \\
29.8\end{array}$ \\
\hline Race: & & & & \\
\hline $\begin{array}{l}\text { White } \\
\text { Nonwhite }\end{array}$ & $\begin{array}{l}36.9 \\
35.6\end{array}$ & $\begin{array}{l}38.6 \\
40.1\end{array}$ & $\begin{array}{l}51.7 \\
50.6\end{array}$ & $\begin{array}{l}27.9 \\
25.5\end{array}$ \\
\hline Education: & & & & \\
\hline$<9^{*}$ & 34.9 & 36.3 & 48.5 & 25.9 \\
\hline $\begin{array}{l}9-12 \\
\geq 12\end{array}$ & 37.1 & 38.4 & 52.0 & 28.6 \\
\hline $\begin{array}{l}\geq 12 \\
\text { Pension: }\end{array}$ & 42.4 & 48.1 & 61.0 & 31.5 \\
\hline Covered & 33.5 & 38.1 & 50.4 & 21.2 \\
\hline Not covered & 38.1 & 39.0 & 52.1 & 25.0 \\
\hline
\end{tabular}

NOTE. - The sample is restricted to persons who are reemployed in the survey interview immediately following the departure from the career job $(N=2,408)$. Sectoral change is defined to occur if there is a change in the one-digit Standard Industrial Classification (SIC) industry or occupation. Values are in percentages.

* Includes persons not reporting years of education.

7. Nominal earnings over a 3-year period ending 2 years before the end of the career job are compared to an equivalent period beginning a year thereafter. Only $5.5 \%$ of persons not changing career jobs prior to age 60 have equivalently large reductions over a corresponding period (with the base year for the comparisons chosen randomly). Greater detail on postcareer earnings changes is provided in Ruhm (1990). 
Interestingly, women maintain attachment to the career industry more often than men $(40.5 \%$ vs. $35.9 \%)$ and are especially likely to remain in the same occupation (49.3\% vs. $36.4 \%)$. This may result from the narrower occupational distribution of female employment or because of unobserved differences in labor force attachment or reemployment success.

Partial retirement almost always involves a change of employment sector. Barely a third of partial retirees remain in either the same industry or occupation as their career job, and only one in nine works in the same industry and occupation (row 3). As discussed in Section IV, partial retirement also rarely occurs on the career job.

\section{PARTIAL RETIREMENT}

Many individuals express a desire to "partially retire" at the end of their working lives. Nonetheless, most research on older workers has maintained the dichotomous labor force classification of retired and not retired. This is usually justified by arguing that merging partial retirement into the other categories simplifies the analysis without much loss of generality. Despite research by Gustman and Steinmeier (1984) and Honig and Hanoch (1985) highlighting the importance of partial retirement, the common belief is that this form of reduced labor force participation happens relatively infrequently and that, when it does occur, it lasts for only a short period of time. ${ }^{8}$

This section presents evidence suggesting that partial retirement is both more prevalent and longer lasting than is generally believed. At least half of all workers partially retire at some point in their lifetimes, and the average period between the beginning of partial retirement and full retirement exceeds 5 years; workers almost never partially retire on their career jobs, however. Labor force reentry, after the initial decision to retire, also occurs fairly frequently and is considered in Section V.

Partial retirement is rare prior to age 62, increases rapidly from 62 through 67, and then gradually declines. Fewer than $4 \%$ of 60 - and 61 -year-old respondents began spells of partial retirement during the previous 2 years. Conversely, over $8 \%$ of 62 - and 63 -year-olds, $10 \%$ of those between the ages of 64 and 67, and 6\% of 68- and 69-year-olds initiated partial retirement over the same period.

The first panel of table 5 shows the resulting probabilities that respondents, of given ages, were partially retired at the time of the RHLS interview. At the peak age (66-67), more than a fifth of all respondents were partially retired, and at least a seventh of household heads aged 64-73 were partially retired at any given survey interview. Further, as shown in the second panel of the table, more than $45 \%$ of the sample reported being partially retired during at least one of the six RHLS interviews, over a quarter did so two or more times, and more than an eighth of respondents classified themselves as partially retired at least three times.

8. For example, Burtless (1986, p. 785), in his very careful study on the labor supply effects of unanticipated social security benefit changes, writes, "the average duration of partial retirement is only about three years. By implication partial retirement accounts for only a very small proportion of lifetime labor supply ... and will be treated as indistinguishable from full retirement." 


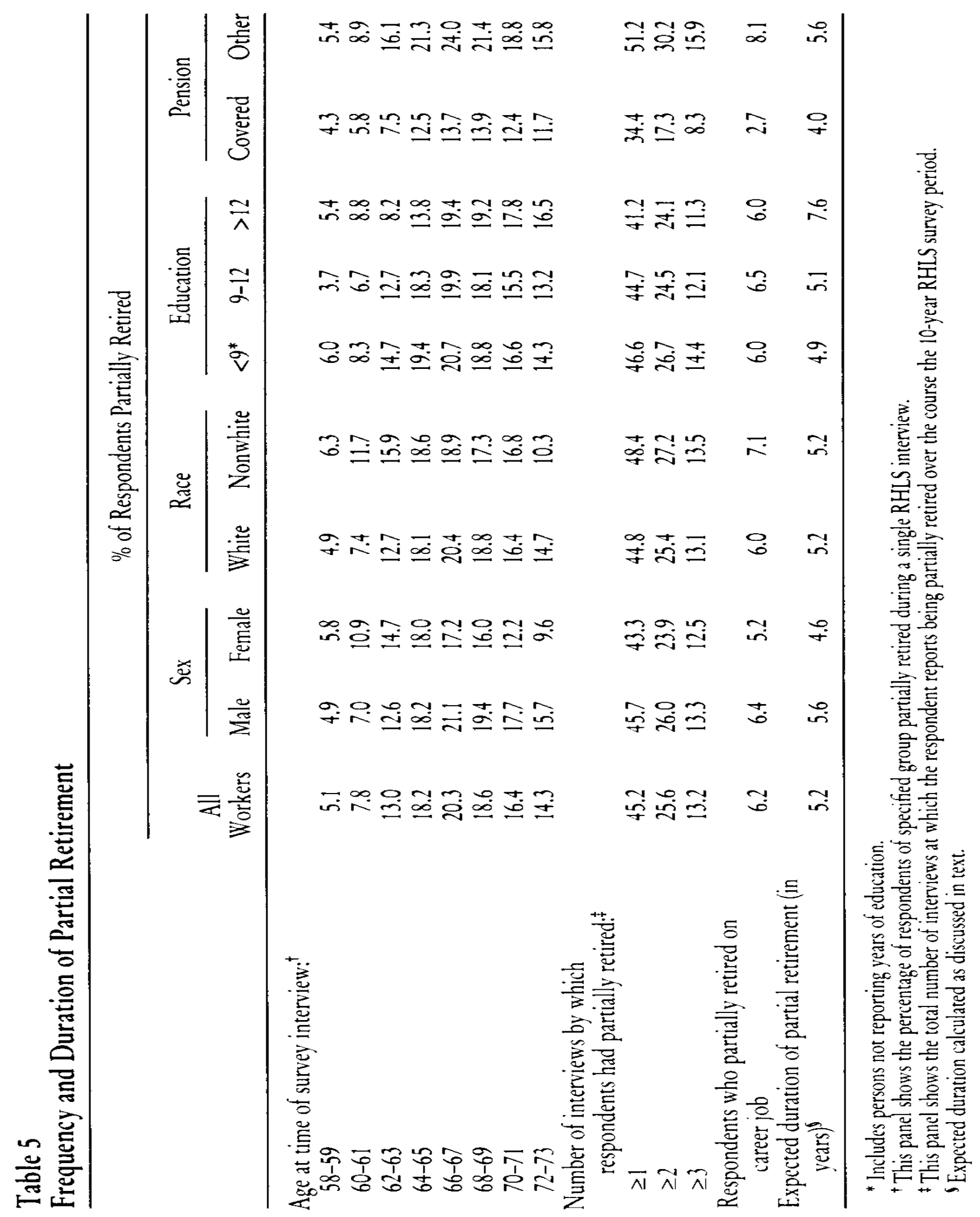


Whites, educated workers, females, and individuals covered by pension plans (in their career jobs) partially retired less often than their counterparts during the observation period. The race and education differences are sensitive to the timing of partial retirement, however, with whites and high school graduates more likely to remain partially retired at later ages. ${ }^{9}$

Partial retirement almost always occurs outside the career job. As displayed in the third panel of table 5, fewer than one in seven partial retirees remains on the career position, which implies that only $6.2 \%$ of all respondents are both partially retired and working for their career employer. These proportions vary only slightly across demographic groups. The only significant difference is by pension status on the career job. Covered workers are only a third as likely to partially retire on the career position as are their noncovered counterparts. Nonetheless, even among the latter group, fewer than one in six workers partially retires without first terminating career employment.

The probability that workers will partially retire during their lifetime is understated in the RHLS since spells ending prior to 1969 or beginning subsequent to 1979 are excluded. Some indication of the size of the underestimate can be obtained by noting that approximately half $(49.2 \%)$ of persons retiring after 1969 partially retire at some point during the 10- year observation period. Using reasonable assumptions about out-of-sample partial retirement behavior and the duration of in-progress spells, I estimate that at least $50 \%$ of respondents partially retire at some point in their working lives. ${ }^{10}$

Although the typical partial retirement spell is fairly short, a considerable proportion last for significant periods of time. Thus, where over $40 \%$ of partial retirements starting after 1969 terminate within 2 years, almost $30 \%$ exceed 6 years, and more than a fifth surpass 8 years. The extended right tail of the distribution results because hazard rates (conditional exit probabilities) decline with the duration of partial retirement. The full-sample 2-year hazard rates are 0.413 , $0.325,0.288$, and 0.256 moving from 0 to 8 years duration. ${ }^{11}$

It is straightforward to calculate the average completed duration of the $79.1 \%$ of partial retirement spells expected to finish in less than 8 years as 2.62 years. ${ }^{12}$ This figure understates the duration of partial retirement, however, because long spells are most likely to be censored. ${ }^{13}$

9. The regression estimates presented in table 8 (col. 1) indicate that, ceteris paribus, nonwhites and less educated workers partially retire less often than their counterparts.

10. For example, if partial retirement probabilities are 1.0\%, 3.0\%, 11.5\%, 8.5\%, and 5.0\% for 54-55, 56-57, 74-75, 76-77, and 78-79-year-olds, respectively (with no partial retirement among workers younger than 54 or older than 79), and $40 \%$ of new spells end within a 2-year period, then $51.7 \%$ of the sample is expected to partially retire during their lifetime.

11. The associated unconditional exit probabilities are 0.413, 0.191, 0.114, and 0.073, respectively. Respondents beginning partial retirement spells prior to the 1969 survey are excluded to eliminate initial condition problems that occur if continuation probabilities of existing spells differ from those of new spells. The duration of partial retirement is defined as the number of years from the first occurrence of partial retirement until full retirement. Thus, transitions from partial retirement to "not retired" do not end the spell.

12. The calculation is as follows: $[0.413 \times 1+0.191 \times 3+0.114 \times 5+0.073 \times 7]=2.07$; $2.07 / 0.791=2.62$. This assumes that spells terminate at the midpoint between survey interviews.

13. Duration estimates could be biased upwards if spells ending prior to 1969 or beginning after 1979 are relatively short. Available data on age differences provide no evidence that this is the case. 
A more reasonable estimate of the completed duration can be obtained by assuming that, beyond 8 years, 2-year hazard rates remain constant at the final observed level. In this case, the expected remaining duration of spells that have reached 8 years is 6.81 years $(2 / 0.256-1)$, and the expected completed duration of all spells is 5.17 years.

The fourth panel of table 5 displays expected partial retirement durations calculated as just discussed. Differences across population subgroups are generally quite small, except when the sample is stratified by education or pension status. High school graduates stay partially retired for approximately 50\% longer than their less schooled peers. Pension-covered workers not only partially retire less frequently but, conditional on doing so, remain in the state only two-thirds as long as their noncovered counterparts.

\section{REVERSE RETIREMENT}

Older workers typically reduce their labor force commitment as they age, either by a discontinuous movement from full-time career employment to retirement or through a more gradual process involving transitional bridge employment and possibly partial retirement. Nonmonotonic decreases also take place fairly frequently, however. Roughly a quarter of household heads reenter the labor force following retirement (see table 6, col. 3). ${ }^{14}$ Over twothirds of these movements are into partial retirement, rather than full labor force participation, and more than three-quarters occur within 4 years of the initial departure from the labor force (cols. 4 and 5). One in four partial retirees also reverses this status, almost $80 \%$ within 4 years of entering the state (cols. 1 and 2).

Table 6

$\%$ of Respondents Who Reverse Full or Partial Retirement

\begin{tabular}{|c|c|c|c|c|c|}
\hline & \multicolumn{2}{|c|}{ Partial Retirement } & \multicolumn{3}{|c|}{ Full Retirement } \\
\hline & (1) & $(2)$ & (3) & $(4)$ & (5) \\
\hline All Workers & 26.1 & 5.7 & 24.9 & 7.7 & 5.9 \\
\hline \multicolumn{6}{|l|}{ Sex: } \\
\hline $\begin{array}{l}\text { Male } \\
\text { Female }\end{array}$ & 23.0 & $\begin{array}{l}4.9 \\
7.9\end{array}$ & 26.0 & 8.1 & $\begin{array}{l}6.6 \\
3.6\end{array}$ \\
\hline \multicolumn{5}{|l|}{ Race: } & \\
\hline White & 24.3 & 6.0 & 24.7 & 7.4 & 5.8 \\
\hline Nonwhite & 38.3 & 3.7 & 26.9 & 9.6 & 6.7 \\
\hline \multicolumn{6}{|l|}{ Education: } \\
\hline$<9^{*}$ & 25.7 & 6.4 & 26.9 & 9.6 & 5.1 \\
\hline $9-12$ & 25.5 & 3.8 & 23.3 & 5.8 & 6.7 \\
\hline \multirow{2}{*}{\multicolumn{6}{|c|}{ Age in 1971: }} \\
\hline & & & & & \\
\hline $60-61$ & 29.5 & 4.7 & 31.4 & 14.8 & 9.5 \\
\hline $62-63$ & 25.7 & 6.3 & 26.6 & 5.9 & 5.1 \\
\hline $64-65$ & 24.6 & 5.1 & 21.0 & 6.3 & 5.1 \\
\hline \multicolumn{6}{|l|}{ Pension: } \\
\hline Covered & 19.2 & 4.6 & 20.8 & 6.7 & 5.1 \\
\hline Not covered & 28.3 & 6.0 & 27.8 & 8.4 & 6.4 \\
\hline
\end{tabular}

NOTE. - The sample includes persons first partially retiring or fully retiring in $1971(N=617$ and 951 , respectively). Column definitions: col. 1: \% who became "not retired" after partially retiring; col. 2: \%" who became "not retired" more than 4 years after partially retiring; col. 3: \% who reentered the labor force after retiring; col. 4: \% who became "not retired" after retiring; col. 5: \% who reentered the labor force more than 4 years after retiring.

* Includes persons not reporting years of education.

14. The percentages in table 6 apply to respondents who first report being retired or partially retired in 1971. Persons doing so in earlier years are excluded to prevent initial condition problems, and those doing so later are deleted so that the subsample can be followed over a fairly long (8-year) time period. The reverse retirement figures are two to three times as high as the reentry probabilities cited by Diamond and Hausman (1984). The difference is due to the longer time period over which individuals are followed. For example, the 1- and 2-year reentry rates for men aged 60-64 are 13.4\% and 9.6\% in Diamond and Hausman (1984, p. 100), and the 2-year rate for men aged 60-65, in this sample, is $14.4 \%$. 
Reversal of partial or full retirement status is much more common for nonwhites, younger workers, and those without pension coverage in the career job, which suggests that these groups often make labor-supply decisions under considerable uncertainty or that liquidity constraints become binding late in life. Probabilities of reversing full and partial retirement are inversely related for race and gender groups. Males and high school graduates are more likely than their peers to reverse partial retirement but less often reenter the labor force after fully retiring. Current labor-market theories provide little understanding of these demographic group differences, and further research is clearly needed.

\section{REGRESSION ANALYSIS}

This section presents regression estimates for equations describing career- job terminations, bridge employment, partial retirement, and reversals of full and partial retirement. A common vector of regressors includes dummy variables for gender, race, education, marital status, and pension coverage in the career job, as well as a continuous measure of "permanent" income. ${ }^{15}$

Table 7 presents regression results for dependent variables indicating the age at which career jobs end, the number of years of postcareer labor force participation, and the extent of sectoral change following the termination of career positions. Table 8 displays coefficients for equations indicating the extent and duration of partial retirement and the probabilities of reversing full or partial retirement status. Ordinary least squares (OLS) techniques are used for continuous dependent variables where censoring is unimportant, maximum likelihood logit is used with dichotomous dependent variables, and the Cox proportional hazards model is estimated when censoring is significant. Positive hazard coefficients imply increased exit probabilities and

\begin{tabular}{|c|c|c|c|c|c|c|c|}
\hline \multirow{3}{*}{$\frac{\text { Regressor }}{\text { Female }}$} & \multicolumn{7}{|c|}{ Dependent Variable } \\
\hline & \multirow{5}{*}{$\begin{array}{l}\mathrm{AGE} \\
1.495^{*} \\
(.64) \\
.115 \\
(.49) \\
.827 \\
(.56)\end{array}$} & \multirow{5}{*}{$\begin{array}{l}\text { POST } \\
-.348^{*} \\
(.15) \\
-.018 \\
(.12) \\
-.097 \\
(.13)\end{array}$} & \multicolumn{2}{|c|}{ YEARS } & \multirow{5}{*}{$\begin{array}{l}\text { IND } \\
-.440 \\
(.23) \\
-.238 \\
(.16) \\
-.041 \\
(.20)\end{array}$} & \multirow{5}{*}{$\begin{array}{l}\text { OCC } \\
-.785^{\text {*** }} \\
(.23) \\
.305 \\
(.16) \\
.075 \\
(.20)\end{array}$} & \multirow{5}{*}{$\begin{array}{l}\mathrm{BOTH} \\
-.752^{* *} \\
(.23) \\
.297 \\
(.16) \\
.020 \\
(.19)\end{array}$} \\
\hline & & & $\begin{array}{l}.096 \\
(.09)\end{array}$ & $\begin{array}{l}-1.3 \mathrm{E}-3 \\
(.09)\end{array}$ & & & \\
\hline Nonwhite & & & .061 & .095 & & & \\
\hline Married & & & $\begin{array}{l}(.07) \\
-.038\end{array}$ & $\begin{array}{l}(.07) \\
-.134\end{array}$ & & & \\
\hline Education: & & & $(.08)$ & $(.4$ & & & \\
\hline & $\begin{array}{l}-.340 \\
(.31)\end{array}$ & $\begin{array}{l}.019 \\
(.07)\end{array}$ & $\begin{array}{l}.117^{*} \\
(.05)\end{array}$ & $\begin{array}{l}.138^{* *} \\
(.05)^{*}\end{array}$ & $\begin{array}{l}.090 \\
(.10)\end{array}$ & $\begin{array}{l}-.020 \\
(.10)\end{array}$ & $\begin{array}{l}.017 \\
(.10)\end{array}$ \\
\hline$>12$ & $\begin{array}{l}.369 \\
(.84)\end{array}$ & $\begin{array}{l}-.052 \\
(.10)\end{array}$ & $\begin{array}{l}-.279^{* *} \\
(.07)\end{array}$ & $\begin{array}{l}-.351 * * \\
(.07)\end{array}$ & $\frac{-.003}{(.15)}$ & $\begin{array}{l}-.477^{* * *} \\
(15)\end{array}$ & $\frac{-.286}{(.15)}$ \\
\hline Income $\div 1,000$ & $\begin{array}{l}.564 * * \\
(.14)\end{array}$ & $\frac{-.131 * *}{(.03)}$ & $\begin{array}{l}.026 \\
(.02)\end{array}$ & $\begin{array}{l}.000 \\
(.02)\end{array}$ & $\begin{array}{l}-.249^{* * *} \\
(.05)\end{array}$ & $\begin{array}{l}-.253 * * \\
(.05)\end{array}$ & $\begin{array}{l}-.330 * * \\
(.05)\end{array}$ \\
\hline Pension & $\begin{array}{l}4.54 * * \\
(.31)\end{array}$ & $\begin{array}{l}-1.150 * * \\
(.07)\end{array}$ & $\begin{array}{l}.563 * * \\
(.05)\end{array}$ & $\begin{array}{l}.262^{* *} \\
(.05)\end{array}$ & $\begin{array}{l}.350^{* *} \\
(.11)\end{array}$ & $\begin{array}{l}.189 \\
(.11)\end{array}$ & $\begin{array}{l}.300 * * \\
(11)\end{array}$ \\
\hline Age career job ends & & & & $\begin{array}{c}.143 * * \\
(3.7 \mathrm{E}-3)\end{array}$ & & & \\
\hline Estimation technique & OLS & LOGIT & HZRD & HZRD & LOGIT & LOGIT & LOGIT \\
\hline
\end{tabular}

15. Permanent income is measured as average annual social security earnings during the 1951-60 period. Years with zero earnings are deleted, and individuals receiving positive earnings in fewer than 5 of the 10 years are excluded. Permanent income has been linked to retirement ages by many researchers (e.g., Boskin and Hurd 1978; Burkhauser 1979; Gordon and Blinder 1980; Mitchell and Fields 1984). 
Table 8

Regression Estimates for Partial and Reverse Retirement

\begin{tabular}{|c|c|c|c|c|c|c|}
\hline \multirow{3}{*}{$\frac{\text { Regressor }}{\text { Female }}$} & \multicolumn{6}{|c|}{ Dependent Variable } \\
\hline & \multirow{5}{*}{$\begin{array}{l}\text { PART } \\
-.458^{* *} \\
(.13) \\
. .274^{* *} \\
(.10) \\
.240^{*} \\
(.12)\end{array}$} & \multirow{5}{*}{$\begin{array}{l}\text { YRSPRT } \\
.130 \\
(.16) \\
.128 \\
(.11) \\
.043 \\
(.14)\end{array}$} & \multicolumn{2}{|c|}{ RVPRT } & \multicolumn{2}{|c|}{ RVRET } \\
\hline & & & .492 & .501 & .233 & .245 \\
\hline Nonwhite & & & $.705 *$ & $.716 *$ & -.212 & -.271 \\
\hline & & & $(.31)$ & $(.31)$ & $(.30)$ & $(.31)$ \\
\hline Married & & & $\begin{array}{l}-.052 \\
(.37)\end{array}$ & $\begin{array}{l}-.046 \\
(.38)\end{array}$ & $\begin{array}{l}.863^{*} \\
(.377)\end{array}$ & $\begin{array}{l}.889^{*} \\
(.379)\end{array}$ \\
\hline \\
\hline$<9$ & $\begin{array}{l}-.161^{*} \\
(.06)\end{array}$ & $\begin{array}{l}.018 \\
(.07)\end{array}$ & $\begin{array}{l}-.155 \\
(.24)\end{array}$ & $\begin{array}{l}-.167 \\
(.25)\end{array}$ & $\begin{array}{l}-.024 \\
(.20)\end{array}$ & $\begin{array}{l}-.026 \\
(.20)\end{array}$ \\
\hline$>12$ & .024 & -.179 & .500 & .490 & -.249 & -.227 \\
\hline & $(.09)$ & $(.10)$ & $(.36)$ & $(.36)$ & $(.31)$ & $(.31)$ \\
\hline Income $\div 1,000$ & $\begin{array}{l}-.330 * * \\
(.03)\end{array}$ & $\begin{array}{l}.071^{*} \\
(.03)^{2}\end{array}$ & $\begin{array}{l}.038 \\
(.10)\end{array}$ & $\begin{array}{l}.037 \\
(.10)\end{array}$ & $\begin{array}{l}-.227^{*} \\
(.09)\end{array}$ & $\begin{array}{l}-.223^{*} \\
(.09)\end{array}$ \\
\hline Pension & $-.538 * *$ & .136 & -.395 & -.399 & -.259 & -.284 \\
\hline \\
\hline $60-61$ & & & & $\begin{array}{l}.070 \\
(.28)\end{array}$ & & $\begin{array}{l}.574^{*} \\
(.24)\end{array}$ \\
\hline $62-63$ & & & & $\begin{array}{l}-.247 \\
(.25)\end{array}$ & & $\begin{array}{l}.426^{*} \\
(.19)\end{array}$ \\
\hline Estimation technique & LOGIT & HZRD & LOGIT & LOGIT & LOGIT & LOGIT \\
\hline
\end{tabular}

reduced state durations. The regression estimates are in general agreement with the cross-tabular findings of Sections III-V.

The pension coefficients are particularly striking and in accord with the findings of previous research (e.g., Mitchell and Fields 1984; Allen, Clark, and McDermed 1988; Kotlikoff and Wise 1989). Workers covered by pension plans hold career jobs longer, work less often and for a shorter periods of time in bridge jobs, and less frequently partially retire. Conditional on remaining in the labor force, they more frequently switch employment sectors, which may be partially explained by job restrictions in some pension schemes, and also reverse full or partial retirement relatively rarely.

Highly paid and educated individuals also remain in career jobs until relatively late ages, have low rates of postcareer labor force participation, and infrequently reverse retirement status. However, conditional on remaining in the labor force, they have average or relatively long durations of bridge employment, low rates of sectoral change, and (for educated workers) long durations of partial retirement.

These findings suggest that education, higher earnings, and pension coverage are associated with career employment that provides some combination of firm-specific investments and high job stability. The infrequency of reverse retirement also indicates that these workers make laborsupply decisions with relatively good information and are unlikely to suffer unexpected liquidity constraints late in life. The intergroup differences are also informative. Benefits associated with pension-covered career employment appear to be largely associated with the particular job, those with earnings or education more strongly related to the individual. As a result, educated persons 
and high-wage workers more frequently maintain attachment to both the labor force and sector of career employment after the latter terminates.

Patterns for gender, race, and marital status are less consistent. Females and nonwhites change occupations (and to a lesser extent industries) relatively infrequently when moving from career to bridge employment. This may occur because these groups work in a restricted subset of occupations in both career and postcareer jobs. Limited employment opportunities may also explain the infrequency of partial retirement after departures from career jobs.

Compared to their unmarried counterparts, married persons tend to work in career positions until later ages, hold bridge jobs longer (if they remain in the labor force after the career job ends), more frequently partially retire, and are more likely to reverse retirement status. This is consistent with these individuals having heavy financial responsibilities and high attachment to the labor force. The strong results on reverse retirement may indicate unexpected liquidity constraints, possibly related to the worsening health or financial well-being of a family member.

After controlling for observables, the career jobs of women last until later ages than those of men, possibly because some females delay the start of careers until the end of their childbearing years or because they have more difficulty in initially obtaining stable career employment.

\section{DISCUSSION}

The stylized image of the typical worker who moves directly from stable career employment to complete and permanent retirement fails to capture the workplace realities of most Americans. Instead, the majority of individuals leave career jobs well before retirement and enter a transitional job-stopping period composed of some combination of bridge employment, partial retirement, and reverse retirement. Most bridge jobs are in different industries or occupations from career positions, and partial retirement, which is both more pervasive and longer lasting than has been generally realized, almost never takes place on the career job. Decisions to partially or fully retire do not necessarily represent a permanent reduction in labor force commitment. Nearly a quarter of retired workers reenter the labor force, and a similar percentage of the partially retired return to full participation. Despite the importance of bridge jobs, there is no evidence of frequent job mobility in postcareer employment.

The stable career positions of educated, highly paid, and pension-covered workers suggest a combination of protection from job instability and desirable personal characteristics. Their low rates of reverse retirement may also imply good information and the absence of liquidity constraints. The differential effects of pensions, as compared to either earnings or education, on postcareer labor-force patterns may indicate the greater importance of job attributes for the former and individual characteristics for the latter groups.

The findings highlighted in this article indicate shortcomings in currently popular intertemporal labor-supply models. In particular, little explanation is provided for preretirement departures from career jobs, except when pension or social security incentives induce voluntary mobility. Although many individuals covered by pension plans do remain in the labor force after, the end of career positions, bridge employment is even more prevalent for noncovered workers. Thus, pension-induced quits can explain only a small share of postcareer labor force participation. 
Similarly, since most career jobs end before 62, the age at which social security benefits first can be received, social security incentives are unlikely to account for much of this behavior.

Existing models need to be enriched to explicitly include the possibility of involuntary mobility, decision making under considerable uncertainty, and institutional constraints. For example, models incorporating tied wage/ hours offers could explain why partial retirement usually involves a change of jobs. ${ }^{16}$ Uncertainty might also play an important role in explaining decisions to reverse retirement or partial retirement status and account for some voluntary decisions to leave career jobs at relatively young ages.

Although the RHLS does not indicate the source of mobility out of early-ending career jobs, several pieces of suggestive evidence indicate the importance of involuntary terminations. Turnover frequently involves a change in industry, occupation, or both, which is likely to be costly if sector-specific human capital is important. Recent research (e.g., Horvath 1987; Hamermesh 1989; Ruhm 1989) also reveals that older workers are only partially protected from economic dislocation, which may lead to the termination of career employment.

The rarity with which workers partially retire while remaining on their career jobs almost certainly indicates the important role of institutional considerations. Some of these, such as Employee Retirement Income Security Act (ERISA) regulations and fixed costs associated with fringe benefits, present obvious barriers to partial retirement with the career employer. Other, less well understood constraints are also likely to necessitate job changes by partial retirees and represent fruitful areas for future study.

\section{APPENDIX}

\section{Alternative Definitions of Retirement Status}

The self-reported measures of retirement status, used throughout this article, may be questioned on the grounds that individuals sometimes inaccurately classify themselves. For example, table 3 shows that $37.2 \%$ of respondents leaving career jobs after 1969 but remaining in the labor force never work for another employer. This could indicate substantial self-employment or extended unemployment that lasts until the individual departs from the labor force. However, it could be symptomatic of considerable reporting bias. Similarly, some "reverse retirements" could result from inconsistent self-reporting of labor force status.

These potential problems have led a number of researchers to adopt alternative definitions of retirement status. For example, Gustman and Steinmeier (1984) classify individuals as partially retired if either annual wages or work hours decline more than $40 \%$ from the levels of the job held at age 55. Honig and Hanoch (1985) define persons earning no wages to be fully retired, those receiving 1\%-50\% of their maximum annual earnings as partially retired, and workers earning over 50\% of the maximum as not retired. Similarly, Burtless and Moffitt (1985) look for a discontinuous drop in work hours, possibly in conjunction with the receipt of social security benefits and self-reported status, in deciding when to classify workers as retired.

16. Lundberg (1985) presents evidence suggesting the importance of tied offers; Gustman and Steinmeier (1986) incorporate a discontinuous drop in wages into their structural model of retirement. 
One concern with these alternative definitions is that involuntary reductions in hours or wages might cause individuals to be erroneously classified as partially or completely retired. This is especially problematic if older workers have exceptional difficulties obtaining comparable employment following job displacement. To reduce this problem, but still utilize a relatively "objective" measure of retirement status, I reestimated most of the tables shown in the article using an alternative definition of labor force status that depends on a combination of the selfreported classification and annual earnings. This measure used self- classified status except in the following cases: (1) If annual earnings were less than $\$ 500$, the individual was classified as retired, regardless of self-reported status. (2) If annual earnings were greater than $\$ 500$ and the respondent defined themselves to be retired, they were classified as partially retired. (3) If annual earnings were between $\$ 500$ and $\$ 2,000$ and self-reported status was not retired, the individual was classified as partially retired. The income thresholds were deliberately set quite low to reduce the impact of involuntary hours constraints. Similarly, absolute dollar thresholds, rather than relative measures of earnings loss, were employed to reduce the probability that workers displaced from career jobs and suffering involuntary earnings reductions would be erroneously classified as retired or partially retired. The qualitative findings were insensitive to a variety of alternative criteria and income thresholds that were considered.

Self-reported and "objective" retirement classifications differ considerably. For example, 25.0\% and $41.1 \%$ of persons, respectively, defining themselves as not retired and partially retired in 1975 were reclassified as retired when annual incomes were considered. Conversely, 14.6\% of "retired" and 5.7\% of "not-retired" individuals were redefined as "partially retired." The net effect of these changes was to reduce the percentage of nonretirees, increase the number of retired persons, and slightly raise or lower the number of partial retirees, depending on the survey year. For instance, $19.9 \%, 18.9 \%$, and $61.3 \%$ of respondents classified themselves as not retired, partially retired, and retired, respectively, in 1975, as compared to $13.8 \%, 21.2 \%$, and $65.1 \%$ using the alternative measure.

Despite the sensitivity of retirement status to the classification criteria, few of the article's main findings are materially affected. Using the "objective" definition, the number of workers retiring directly from career jobs declines significantly (from $35.9 \%$ to $21.6 \%$ ), but the number remaining in the labor force for 5 years or more is virtually unchanged (falling from $47.6 \%$ to $46.0 \%$ ). Reverse retirement probabilities rise slightly (from $24.9 \%$ to $25.9 \%$ ), while the percentage of retirees reentering the labor force after more than 4 years of retirement is virtually unchanged (falling from 5.9\% go 5.7\%). That the frequency of reverse retirements is not substantially reduced using the "objective" criteria indicates that the reversals observed above are probably not the result of inconsistent self-reporting.

The one important difference between the self-defined and "objective" classifications is that partial retirement occurs more commonly but lasts for shorter average durations when the latter measure is substituted for the former. Using the "objective" measure, partial retirement probabilities peak at 25.5\% at ages 64 and 65 (vs. 20.3\% at 66 and 67), 58.9\% of respondents are partially retired in at least one survey interview (compared to 45.2\%), and the average duration of partial retirement is 2.9 years (vs. 5.2 years). The discrepancies occur because a large number of individuals receive earnings for a short period of time after they classify themselves as retired. Thus, a substantial number of short spells are introduced. While the frequency and duration of 
partial retirements are sensitive to the classification criteria used, partial retirement is important using either definition.

\section{REFERENCES}

Allen, Steven; Clark, Robert; and McDermed, Ann. "Why Do Pensions Reduce Mobility?"

Working Paper no. 2509. Cambridge, Mass.: National Bureau of Economic Research, 1988.

Boskin, Michael, and Hurd, Michael. "Effects of Social Security on Early

Retirement." Journal of Public Economics 99 (December 1978): 767-90.

Burkhauser, Richard. "The Pension Acceptance Decision of Older Workers." Journal of Human Resources 14 (Winter 1979): 63-75.

Burtless, Gary. "Social Security, Unanticipated Benefit Increases, and the Timing of Retirement." Review of Economic Studies 53 (October 1986): 781-805.

Burtless, Gary, and Moffitt, Robert. "The Joint Choice of Retirement Age and Postretirement Hours of Work." Journal of Labor Economics 3 (April 1985): 209-36.

Diamond, Peter, and Hausman, Jerry. "The Retirement and Unemployment Behavior of Older Men." In Retirement and Economic Behavior, edited by Henry Aaron and Gary Burtless, pp. 97-134. Washington, D.C.: Brookings, 1984.

Feldstein, Martin, "The Economics of the New Unemployment." Public Interest 33 (Fall 1973): 3-42.

Gordon, Roger, and Blinder, Alan. "Market Wages, Reservation Wages, and Retirement Decisions." Journal of Public Economics 14 (October 1980): 277-308.

Gustman, Alan, and Steinmeier, Thomas. "Partial Retirement and the Analysis of Retirement Behavior." Industrial and Labor Relations Review 37 (April 1984): 403-15.

--------. "A Structural Model of Retirement." Econometrica 54 (May 1986): 555-84.

Hall, Robert. "The Importance of Lifetime Jobs in the U.S. Economy." American Economic Review 72 (September 1982): 716-24.

Hamermesh, Daniel S. "What Do We Know about Worker Displacement in the U.S.?" Industrial Relations 28 (Winter 1989): 51-58.

Honig, Marjorie, and Hanoch, Giora. "Partial Retirement as a Separate Mode of Retirement Behavior." Journal of Human Resources 20 (Winter 1985): 21-46.

Horvath, Francis W. "The Pulse of Economic Change: Displaced Workers of 1981-5." Monthly Labor Review 110 (July 1987): 3-12.

Kotlikoff, Laurence, and Wise, David. The Wage Carrot and the Pension Stick. Kalamazoo, Mich.: Upjohn, 1989.

Lundberg, Shelly. "Tied Wage-Hours Offers and the Endogeneity of Wages." Review of Economics and Statistics 66 (August 1985): 405-10.

Mitchell, Olivia, and Fields, Gary. "The Economics of Retirement Behavior." Journal of Labor Economics 2 (January 1984): 84-105.

Osterman, Paul. Getting Started: The Youth Labor Market. Cambridge, Mass.: MIT Press, 1980.

Quinn, J., and Burkhauser, R. "Work and Retirement." In Handbook of Aging and the Social Sciences, 3d ed., edited by Robert Binstock and Linda George, pp.307-27. San Diego, Calif.: Academic Press, 1990.

Ruhm, Christopher. "Displacement Induced Unemployment." Mimeographed. Boston: Boston University, Department of Economics, 1989.

. "Career Employment and Job Stopping." Industrial Relations (1990, in press). 